\title{
CHARACTERISTICS OF GEOPOLYMER USING RICE STRAW ASH, FLY ASH AND LATERITE SOIL AS ECO-FRIENDLY MATERIALS
}

\author{
*Parea R. Rangan ${ }^{1}$, Rita Irmawaty ${ }^{2}$, A. Arwin Amiruddin² and Bambang Bakri² \\ 1,2 Department of Civil Engineering Hasanuddin University, Makassar, Indonesia;
}

*Corresponding Author, Received: 09 March 2020, Revised: 31 March 2020, Accepted: 03 April 2020

\begin{abstract}
This study discusses the utilization of Rice Straw Ash (RSA), Fly Ash (FA) and alkali activator $(\mathrm{NaOH})$ to bind laterite soil (LS). RSA and FA are geopolymer activated with $12 \mathrm{M} \mathrm{NaOH}$. Geopolymer mortar strength was tested, where the percentage ratio of RSA/FA/LS was 16.67/41.67/41.67. Flow testing on fresh geopolymer shows that all materials are well bound and segregation does not occur. Specimen were cured with three variations, namely immersed in water, immersed in $\mathrm{Na}_{2} \mathrm{SO}_{4}$ and immersed in $\mathrm{H}_{2} \mathrm{SO}_{4}$ solution until 28 days to evaluate its durability. The compressive strength and stress-strain relationships are analyzed to study the behaviour of hardened mortar geopolymer. Method of treatment and age of mortar can be effective for compressive strength. The geopolimeryzation show increased strength in the immersion of sulphate solution. The XRF test results confirm that the pozzolanic from RSA can be bound by geopolymers. The results of this reactivity are very promising in terms of the potential reuse of ash in the cementing systems.
\end{abstract}

\section{Keywords: Geopolymer, Rice straw ash, Fly ash, Laterite soil, Compressive strength}

\section{INTRODUCTION}

In Indonesia, almost all of the coal used in this country was burned to produce electricity in coalfired power plants. Fly ash is the main residue from coal combustion. The majority of fly ash is still disposed of in landfills, which creates environmental problems, where the additional cost of landfills is an urgent need in some areas. Therefore, a new recycling approach is needed to produce value-added products from fly ash instead of considering it as waste material to be disposed of. Thus, to create a more friendly environment by conserving non-renewable materials, waste materials such as fly ash can be used. According to ASTM C 618-19 fly ash is divided into three categories namely class $\mathrm{N}$, class $\mathrm{F}$ and class $\mathrm{C}$ [1]. The minimum content of $\mathrm{SiO}_{2}, \mathrm{Al}_{2} \mathrm{O}_{3}$ and $\mathrm{Fe}_{2} \mathrm{O}_{3}$ compounds is $70 \%$ for class $\mathrm{N}$ and class $\mathrm{F}$, while class $\mathrm{C}$ is between $50 \%-70 \%$. The $\mathrm{CaO}$ content in fly ash class $\mathrm{N}$ and $\mathrm{F}$ is relatively small compared to class $\mathrm{C}$, where the content of $\mathrm{CaO}$ class $\mathrm{C}$ is more than $20 \%$ [2].

About $75 \%$ of organic volatile and the remaining $25 \%$ by weight of the husk are converted to ash during the burning process known as rice straw ash. RSA has a very high amount of silica and was found to be amorphous. The amorphous silica contained in RSA can react with cement binding to carry out pozzolanic activity [3]. Rice straw is an agricultural waste which causes several management problems such as field burning causing severe air pollution and natural organic decomposition supporting methane emission [4]. This last process has a strong environmental effect in terms of greenhouse gas emission, because the global warming potential of methane is much higher than $\mathrm{CO}_{2}$, which is 25times more for a 100-year horizon and 72-times more for 20-year horizon [5]. Therefore, it is important to treat this waste because rice production accounts for $5-10 \%$ of methane emissions worldwide. In addition, a large quantity of rice straw is produced throughout the world, where $1-1.5 \mathrm{~kg}$ of straw is produced for every $1 \mathrm{~kg}$ of paddy rice [6].

Cement production, which results in higher $\mathrm{CO}_{2}$ levels, has a negative impact on environment [7-9]. Some recent research and developments of geopolymer have expanded in the area of soil improvement. A study conduct related to technology to improve LA soil using high calcium fly ash-based geopolymer. It was found that fly ash combining curing time could provide the compressive strength [10]. A study conduct focused on technology associated with improving silty clay using FA and high calcium as alkali activator activated by $\mathrm{NaOH}$ dan $\mathrm{Na}_{2} \mathrm{SiO}_{3}$. [11]

The colour of laterite soil varies but is usually brightly coloured. The most common colour shades are pink, red and brown. The physical properties of the laterite soil vary according to the mineralogical composition and the particle size distribution of the soil. Granular may vary from the finest to the gravel according to the origin, thus affecting the geotechnical properties such as plasticity and compressive strength. One of the main advantages of laterite soil material is not easily swelling with water and not too sandy [12]. In this case, efforts to reduce the use of cement 
have been carried out intensively, such as the development of geopolymer that can be produced from various kinds of industrial by-products. Materials that are rich in alumina $\left(\mathrm{Al}_{2} \mathrm{O}_{3}\right)$ and silica $\left(\mathrm{SiO}_{2}\right)$ can be activated with an alkaline solution to produce geopolymer without the addition of Portland cement [13]. Fly ash geopolymer as a binding material in the field of construction and building materials have been studied and developed intensively.

Glukhovsky classified the alkaline activators in six groups based on their chemical composition: Caustic alkalis (MOH), Non-silicate weak acid salts: $\left(\mathrm{M}_{2} \mathrm{CO}_{3}, \quad \mathrm{M}_{2} \mathrm{SO}_{3}, \quad \mathrm{M}_{3} \mathrm{PO}_{4}, \quad \mathrm{MF}\right.$ ect), Silicates: $\mathrm{M}_{2} \mathrm{O} . \mathrm{nSiO}_{2}$ ), Aluminates: $\mathrm{M}_{2} \mathrm{O} . \mathrm{nAl}_{2} \mathrm{O}_{3}$ ), Alumino-silicates: $\left(\mathrm{M}_{2} \mathrm{O} . \mathrm{nAl}_{2} \mathrm{O}_{3} .(2-6) \mathrm{SiO}_{2}\right)$, Nonsilicate strong acid salts: $\left(\mathrm{M}_{2} \mathrm{SO}_{4}\right)$ [14].

Often water from swamps or estuaries that contain sulfates overflows during high-intensity rain. Water containing sulphate compounds such as $\mathrm{Na}_{2} \mathrm{SO}_{4}, \mathrm{H}_{2} \mathrm{SO}_{4}$ is inundated in a region containing laterite soils. Sulfate compounds have the potential to affect laterite soil resistance.

This research uses rice straw ash and fly ash geopolymer-based to bind laterite soil. The composition of geopolymer from rice straw ash, fly ash and laterite soil was made, then was conducted slump flow test and resistance to immersion, both freshwater and sulfate solution $\left(\mathrm{Na}_{2} \mathrm{SO}_{4}\right.$ and $\left.\mathrm{H}_{2} \mathrm{SO}_{4}\right)$ at 28 days. Also, compressive strength and stress-strain relationship will be discussed.

\section{EXPERIMENTAL PROGRAM}

Laboratory studies were carried out to analyze the oxide content of fly ash, rice straw ash and laterite soil by using XRF. Also, compressive strength test was conducted.

\subsection{Materials}

Rice straw is collected from open fields in locally small heaps, in Toraja, South Sulawesi, Indonesia. Then the rice straw is burned in a tin box furnace under controlled conditions (temperature $800-900{ }^{\circ} \mathrm{C}$ ). After that, the fine ash is crushed in the ball mill until the average particle size passes in sieve No. $50(0.3 \mathrm{~mm})(100 \%)$ and $10 \%$ passing sieve No. 100 (0.15 mm).

Fly ash used in this research was collected from Jeneponto coal-burning power plant in South Sulawesi, Indonesia. All fly ash particles pass the sieve No. 200. Table 1 present physical properties of rice straw ash and fly ash.

Table 1. Physical characteristic of RSA and FA

\begin{tabular}{clcc}
\hline No. & Characteristics & RSA & Fly Ash \\
\hline 1 & Specific gravity & 2.36 & 2.65
\end{tabular}

2 Water absorption $\quad 172.78 \% \quad 26.42 \%$

3 Pass sieve No.100 $<10 \% \quad>50 \%$

Laterite soil was obtained from the field in Gowa, South Sulawesi, Indonesia. Laterite soil is processed until it passes the sieve No. 8 (2.36 mm). Engineering properties of laterite soil is shown in Table 2. This soil is classified as heavy clay $(\mathrm{CH})$ according to the Unified Soil Classification System (USCS) (ASTM D2487-17) and A-7-5 according to the AASHTO (ASTM 2009).

Geopolymer mortar mixture is activated with an alkaline solution, namely sodium hydroxide $(\mathrm{NaOH})$ solution with a concentration of 12 Molar. Fig. 1 show the geopolymer materials.

Table 2. Engineering properties of laterite soil

\begin{tabular}{ccc}
\hline No. & Characteristics & Laterite Soil \\
\hline 1 & Specific gravity & 2.65 \\
2 & Plastic limit (PL) & $33.90 \%$ \\
3 & Liquid limit (LL) & $65.46 \%$ \\
4 & Plastic index & 31.57 \\
\hline & \\
\hline
\end{tabular}

Fig 1. Geopolymer mortar materials

\subsection{Specimens}

Geopolymer mortar is formed from a mixture of Soil Laterite - RSA - FA with sodium hydroxide as an activator. The ratio between RSA: FA: LS is 16.67: 41.67: 41.67. From preliminary research, the composition of mortar geopolymers was obtained, as presented in Table 3 . $\mathrm{NaOH}$ solution was used as an alkaline binder. The amount of water used is carefully calculated to get optimum compaction of laterite soil.

Table 3. Geopolymer mortar mix $\left(1 \mathrm{~m}^{3}\right)$

\begin{tabular}{ccccc}
\hline $\begin{array}{c}\text { Water } \\
(\mathrm{kg})\end{array}$ & $\begin{array}{c}\mathrm{NaOH} \\
(\mathrm{kg})\end{array}$ & $\begin{array}{c}\text { Rice } \\
\text { straw } \\
\text { ash } \\
(\mathrm{kg})\end{array}$ & $\begin{array}{c}\text { Fly Ash } \\
(\mathrm{kg})\end{array}$ & $\begin{array}{c}\text { Laterite } \\
\text { Soil } \\
(\mathrm{kg})\end{array}$ \\
\hline 125.690 & 60.392 & 60.392 & 150.979 & 150.979 \\
\hline
\end{tabular}

The specimen is cylindrical in diameter $50 \mathrm{~mm}$ and height $100 \mathrm{~mm}$. There are 3 variations of curing namely immersed in water, immersed in $2 \%$ $\mathrm{Na}_{2} \mathrm{SO}_{4}$ solution and immersed in $2 \% \mathrm{H}_{2} \mathrm{SO}_{4}$ solution until the age of the testing.

Flow or consistency tests indicate the ease of fresh geopolymer mortar mixtures to be formed, 
with reference to SNI 03-6825-2002. The ratio of water to solids is 0.2 with a flow target of $110 \pm$ $5 \%$. The flow value is then maintained for each mixed design.

\section{RESULTS AND DISCUSSION}

\subsection{Oxide Content of Rice Straw Ash, Fly Ash and Laterite Soil}

From the XRF analysis results was obtained oxide content of rice straw ash, fly ash and laterite soils as presented in Table 4. Rice straw ash contain $\mathrm{SiO}_{2}, \mathrm{P}_{2} \mathrm{O}_{5}, \mathrm{CaCO}_{3}$ and $\mathrm{K}_{2} \mathrm{O}$. Fly ash used in this study is categorized as class $\mathrm{F}$ because it has a total content of $\mathrm{Fe}_{2} \mathrm{O}_{3}, \mathrm{Al}_{2} \mathrm{O}_{3}$, and $\mathrm{SiO}_{2}$ greater than $70 \%$. The density of fly ash is 2.65 $\mathrm{gr} / \mathrm{cm}^{3}$ and the weight of the laterite soil type is $2.65 \mathrm{gr} / \mathrm{cm}^{3}$.

Table 4. Oxide content of fly ash, rice straw ash and laterite soil

\begin{tabular}{cccc}
\hline \multirow{2}{*}{$\begin{array}{c}\text { Oxide } \\
\text { Content }\end{array}$} & Fly ash & $\begin{array}{c}\text { Rice } \\
\text { straw ash }\end{array}$ & $\begin{array}{c}\text { Laterite } \\
\text { soil }\end{array}$ \\
\cline { 2 - 4 } $\mathrm{Fe}_{2} \mathrm{O}_{3}$ & 19.96 & 2.31 & 12.49 \\
$\mathrm{Al}_{2} \mathrm{O}_{3}$ & 19.16 & - & 49.38 \\
$\mathrm{SiO}_{2}$ & 34.63 & 70.80 & 34.81 \\
$\mathrm{MnO}$ & 0.25 & - & 0.10 \\
$\mathrm{TiO}_{2}$ & 1.26 & - & 1.39 \\
$\mathrm{~K}_{2} \mathrm{O}$ & 1.33 & 15.89 & 0.35 \\
$\mathrm{CaO}$ & 12.74 & 5.34 & 0.85 \\
$\mathrm{P}_{2} \mathrm{O}_{5}$ & - & 3.61 & 0.44 \\
$\mathrm{~V}_{2} \mathrm{O}_{5}$ & - & - & 0.06 \\
$\mathrm{ZrO}_{2}$ & - & - & 0.05 \\
$\mathrm{SrO}$ & 0.13 & - & 0.03 \\
$\mathrm{Cr}_{2} \mathrm{O}_{3}$ & 0.07 & - & 0.02 \\
$\mathrm{CuO}$ & - & - & 0.02 \\
$\mathrm{ZnO}_{\mathrm{MgO}}$ & - & - & 0.011 \\
$\mathrm{SO}_{3}$ & 8.1 & - & - \\
$\mathrm{CoO}$ & 1.80 & - & - \\
$\mathrm{BaO}$ & 0.05 & - & - \\
$\mathrm{Pr}_{6} \mathrm{O}_{11}$ & 0.21 & - & - \\
$\mathrm{Nd}_{2} \mathrm{O}_{3}$ & 0.07 & - & - \\
\hline & & - & - \\
\hline
\end{tabular}

\subsection{Flow Testing}

The flow of fresh mortar geopolymer is 112.50 $\mathrm{mm}$ with specific gravity in fresh conditions is $1901.3 \mathrm{~kg} / \mathrm{m}^{3}$. Geopolymer mortar mixes can bind laterite soil well, therefore fresh mortar geopolymers can flow and spread evenly without segregation and bleeding in the center of the circle. Fig 2 shows the flow of fresh mortar geopolymers.

\subsection{Stress-Strain Behavior}

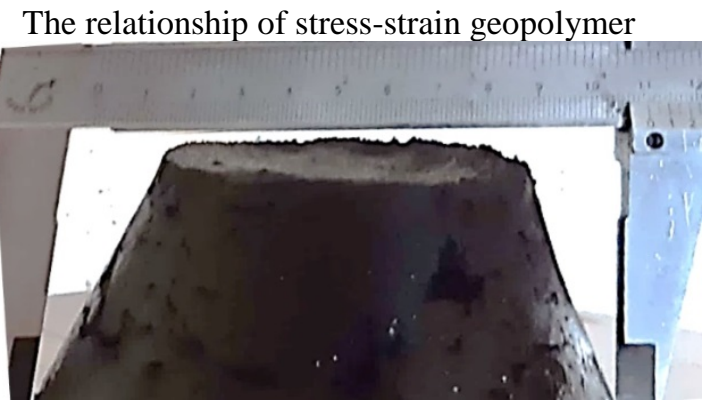

Fig 2. The flow of fresh mortar geopolymer

mortar with curing variation is shown in Fig 3-5. As shown in the figure, the linear stress-strain relationship is $78 \%, 80 \%$ and $82 \%$ of the peak stress in each specimen which is cured by immersion in water, $\mathrm{Na}_{2} \mathrm{SO}_{4}$ solution and $\mathrm{H}_{2} \mathrm{SO}_{4}$ solution, respectively. Also, it appears that all specimens have elasticity, this indicates that shrinkage that occurs after being immersed in water keeps the specimen elastic. After reaching the peak stress, the stress decreases but the strain continues to increase. This shows that the geopolymer mortar, although fragile, is not destroyed suddenly.

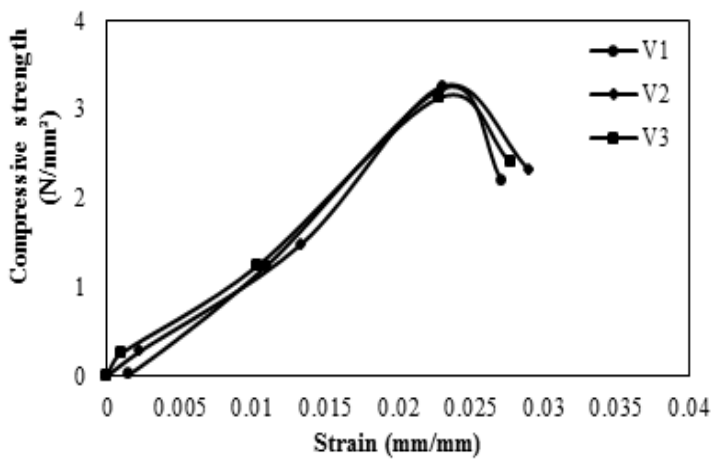

Fig 3. Stress-strain relationship of specimens immersed in the water

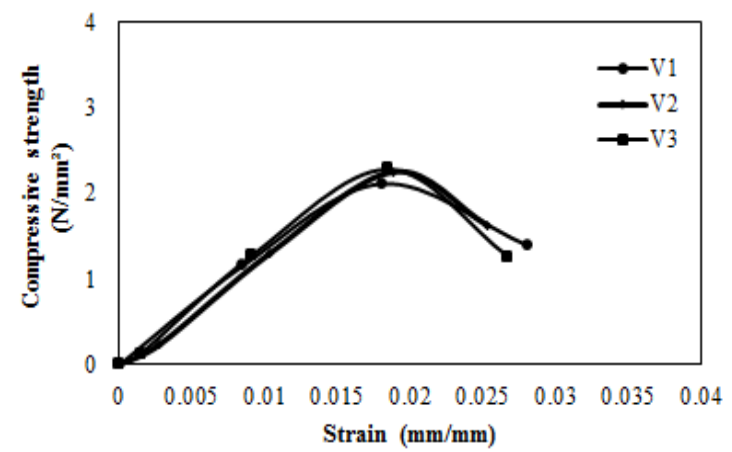

Fig 4. Stress-strain relationship of specimens immersed in $\mathrm{Na}_{2} \mathrm{SO}_{4}$ solution 


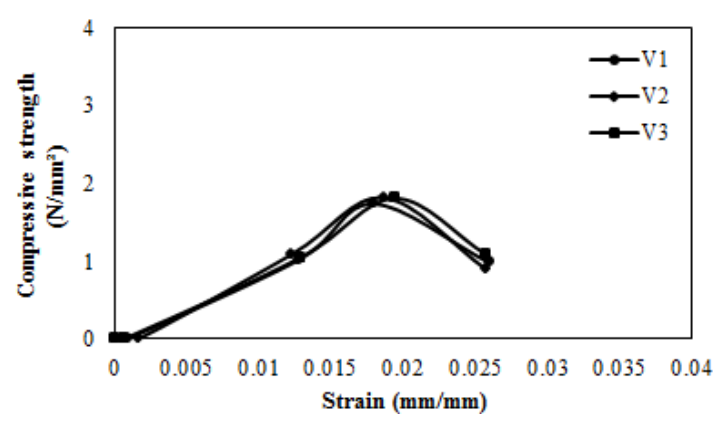

Fig 5. Stress-strain relationship to the test specimens immersed in $\mathrm{H}_{2} \mathrm{SO}_{4}$ solution

The compressive strength values for various curing variations are presented in Figure 6. There is a decrease in the strength of $31 \%$ and $44 \%$, if the Geopolymer mortar is immersed in the solution of $\mathrm{Na}_{2} \mathrm{SO}_{4}$ and $\mathrm{H}_{2} \mathrm{SO}_{4}$. This shows that the binding process between materials is disturbed by the sulfate environment, resulting in a significant decrease in strength. Although visually, it does not appear to be defective in the test specimen.

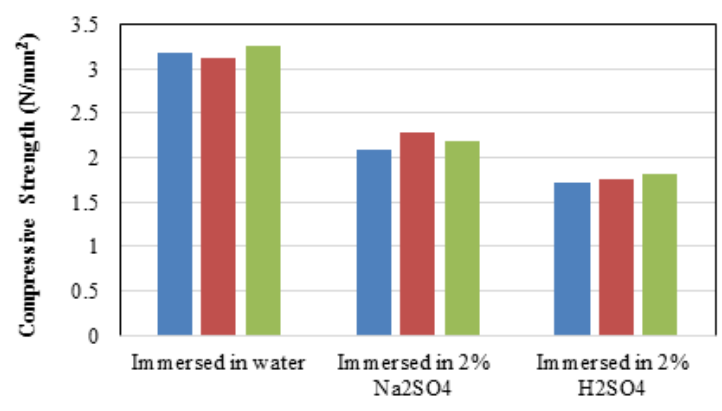

Fig 6. Compressive strength of geopolymer mortar

This shows that mortar geopolymers have resistance to immersion in a sulfate environment of up to $2 \%$ without interfering the binding process.

Similar with the samples those cured in the water, the presence of rice straw ash in the mortar mix, even without high-temperature curing, the fly ash geopolymer mortar with laterite soil material are still able to provide strength. This is due to the presence of rice straw ash in a mixture of mortars that contribute to heat. These results indicate that the compressive strength of mortar due to $\mathrm{SiO}_{2}$ oxide content of rice straw ash, laterite soil and fly ash are able to bind well and produce amorphous silica.

In Figure 6 shows that the specimens immersed in $\mathrm{Na}_{2} \mathrm{SO}_{4}$ and $\mathrm{H}_{2} \mathrm{SO}_{4}$ solution compressive strength decreased. This is caused by ions from the sulfate reacting with geopolymer mortar binding agents thereby reducing the binding capacity between the binder (alkali activator) and geopolymer material (RSA, FA and LS). Exposure to sulfate solutions can cause a significant reorganization of the mortar microstructure. The penetration of sulfate ions into the material not only comes from sulfate bearing phase precipitation (such as ettringite and gypsum) but also results in dissolution of calcium hydroxide and decalcification of C-S-H.

\section{CONCLUSION}

From the results and discussion, it can be concluded as follow:

1. In fresh condition, the mortar geopolymer can bond well without segregation and bleeding.

2. The sodium hydroxide $(\mathrm{NaOH})$ releases the silica and alumina in the amorphous phase and act as a binder.

3. Compressive strength development of geopolymer mortar using RSA, FA and LS remain steady at $2 \% \mathrm{Na}_{2} \mathrm{SO}_{4}$ and $\mathrm{H}_{2} \mathrm{SO}_{4}$ immersion.

\section{ACKNOWLEDGEMENTS}

Authors wishing to acknowledge assistance or encouragement from colleagues, special work by technical staff or financial support from organizations should do so in an unnumbered-

\section{REFERENCES}

[1] ASTM C 618-19. 2019. Standard Specification for Coal Fly Ash and Raw or Calcined Natural Pozzolan for Use in Concrete.

[2] Temuujin, J., et. al. 2009. Influence of Calcium Compounds on The Mechanical Properties of Fly Ash Geopolymer Pastes. Journal of Hazardous Materials 167 : 82-88.

[3] V. M. Malhotra, "Introduction: sustainable development and concrete technology,” ACI Concrete International, vol. 2, p. 4, 2002.

[4] Yuan, Q., Pump, J., Conrad, R., 2014. Straw application in paddy soil enhances methane production also from other carbon sources. Biogeoscience 11,237-246, http://dx.doi.org/10.5194/bg-11-237-2014.

[5] IPCC, 2007. International Panel on Climate Change. Climate Change. The Physical Science Basis. Cambridge University Press, Cambridge https://www.ipcc.ch/publications and data/publications ipcc fourth assessment report wg1report the physical science basis.htm (accessed 28.07.16).

[6] Binod, P., Sindhu, R., Singhania, R.R., Vikram, S., Devi, L., Nagalakshmi, S., Kurien, N., Sukumaran, R.K., Pandey, A., 2010. Bioethanol production from rice straw: an overview. Bioresour. Technol. 101, 4767-4774, http://dx.doi.org/10.1016/j.biortech.2009.10.07 
$\underline{9}$.

[7] Ahmad I. A., Parung H., Tjaronge M. W. and Djamaluddin R. 2013. Corrosion of Concrete Using Portland Composite Cement and Rice Husk Ash Under Simulated Acid Rain Environment. Advanced Research Materials. Trans Tech Publications, 789 : 511-514.

[8] Du Y. J., Yu B. W., Jiang N. J and Liu M. D. 2016. Physical, Hydraulic, and Mechanical Properties of Clayey Soil Stabilized by Lighweight Alkali-Activated Slag Geopolymer. American Society of Civil Engineers. DOI: 10.1061/(ASCE)MT.1943-5533.0001743.

[9] Wangsa F. A., Tjaronge, M.W., Djamaluddin A. R. and Muhiddin A. B. 2017. Effect of hydrated lime on compressive strength mortar of fly ash laterite soil geopolymer mortar. IOP Conf. Series: Materials Science and Engineering $271 \quad$ (2017) 012068 doi:10.1088/1757-899X/271/1/012068

[10] Phummiphan, I., Horpibulsuk, S., Sukmak, P., Chinkulkijniwat, A., Arulrajah, A., Shen, S.L., 2016. Stabilization of marginal lateritic soil using high calcium fly ash-based geopolymer. Road Materials and Pavement Design http://dx.doi.org/10.1080/14680629.2015.113 $\underline{2632}$.
[11] Phetchuay, C., Horpibulsuk, S., Suksiripattanapong, C., Chinkulkijniwat, A., Arulrajah, A., Disfani, M.M., 2014. Calcium carbide residue: alkaline activator for clay-fly ash geopolymer. Constr. Build. Mater. 69, 285-294. Maignien, R. 1966. Review of Research on Laterite, Natural Resource Research IV; UNESCO: Paris, France; p. 148.

[12] Pacheco-Torgal, Fernando, et. al. 2008. Alkali-activated Binders: A Review Part 1. Historical Background, Terminology, Reaction Mechanisms and Hydration Products. Construction and Building Materials 22: 1305-1314.

[13] Matalkah F., Soroushian P., Balchandra A. and Peyvandi A. Characterization of AlkaliActivated Nonwood Biomass Ash-Based Geopolymer Concrete. DOI: 10.1061/(ASCE)MT.1943-55330001801. American Society of Civil Engineers. 2016.

[14] Fernández-Jiménez A, Palomo JG, Puertas F. Alkali-activated slag mortars mechanical strength behaviour. Cem. Concr Res 1999; 29:1313-21.

Copyright (C) Int. J. of GEOMATE. All rights reserved, including the making of copies unless permission is obtained from the copyright proprietors. 